\title{
Influence of Organic Manures on Number Effective Tillers per Plant, Leaf Area (LA) and Leaf Area Index (LAI) in Wheat (Triticum aestivum L.)
}

\author{
Ch. Siva Naga Lakshmi ${ }^{1}$, Narendra Singh ${ }^{2}$, Gajendra Singh ${ }^{1}$, \\ Ankush Singh ${ }^{1}$ and Pragya Rawat ${ }^{3}$
}

\author{
${ }^{1}$ Department of Agronomy, ${ }^{2}$ Department of Veterinary Sciences, ${ }^{3}$ Department of \\ Biotechnology, Alpine Institute of Technology, Premnagar, Dehradun (U.K), India
}

*Corresponding author

\begin{abstract}
A B S T R A C T
The Wheat crop use of inorganic fertilizers for the past 50 years without any addition of organic manures resulted in the large scale deficiency of micro

\section{Keywords}

Organic manures, vermicompost and farmyard manure

\section{Article Info}

Accepted:

12 February 2020

Available Online:

10 March 2020 nutrients which play an important role in enhancing the quality and quantity of the agriculture produce. Further nutrient losses in inorganic fertilizer is very high and loss of nutrients like $\mathrm{NO}_{3}$ sometime leads to water pollution. The present experiment consist of nine treatments $\mathrm{T}_{1}$ : RDF, $\mathrm{T}_{2}$ : EC (1/4) basal + PM (3/4) basal, T $:$ FYM (1/4) basal + VC (3/4) basal, T $:$ FYM (1/4) basal + PM (3/4) basal, T : EC (1/4) basal + VC (3/4) basal, T6: FYM (1/4) basal + PM (3/4) top dressing 30DAS, T 7 : EC (1/4) basal + VC (3/4) top dressing @ $30 \mathrm{DAS}, \mathrm{T}_{8}$ : EC (1/4) basal + PM (3/4) top dressing at 30DAS, T9: Control. The study revealed that, among the treatments, $\mathrm{T}_{8}$ treatment i.e., $\mathrm{T}_{8}$ : EC (1/4) basal + PM (3/4) top dressing at 30 DAS observed the highest leaf area at 30 DAS and 60 DAS (i.e., 15.77 and 24.12) and highest leaf area index at 30 DAS and 60 DAS (i.e., 16.70 and 2.637), more number of effective tillers per plant at 60DAS and at harvest (i.e., 116.00 and 126.66).
\end{abstract}

\section{Introduction}

Wheat crop is very much essential to find out the alternative to the chemical fertilizers which maintain the soil fertility and enhance the productivity of crops. Under such situation the use of organic manures in agriculture play an important role. In this context, a keen awareness has to be created on the adoption of organic farming as a remedy to maneuver the ill effects from chemical farming. The increasing leaf area index may be due to repeated mineralization and nutrient availability of poultry manure Subbareddy et 
al., (2008) the increasing leaf area may be due to increasing amount of protoplasm along with proteins, which lead to increase turgidity of plant cells. This resulted in the expansion of cell wall, which was manifested in the increased linear and lateral dimensions of leaves and stalk of the plant.

In organic farming, the first and foremost characteristic is protecting fertility and nutrition management (nitrogen selfsufficiency). The total nutritional consumption (NPK) from chemical fertilizers is about 20.34 million $t$ (Arun Kumar 2009) in India. To substitute the same in organic farming, enough sources like crops residues, legume crop rotations with BNF, nonsymbiotic $\mathrm{N}_{2}$ fixation, animal dung and urine, composts, green manures, plant based nutrients, mineralization of nutrients, nutrient transformations, etc., are the greater options available with us on the farm.

Organic manures in agriculture add much needed organic and mineral matter to the soil. The organic matter added is an indispensable component of soil, and plays an important role in maintenance and improvement of soil fertility and productivity. The proper management of these makes it possible to increase the efficiency of use of soil and added nutrients.

\section{Materials and Methods}

\section{Seed source}

For the present study, seeds of wheat variety PBW-550 were obtained from Dept. of agriculture Dehradun, Uttarkhand.

\section{Description of variety}

The wheat variety PBW 550 is a yellow rust resistant version of PBW 550. Its average plant height is $86 \mathrm{~cm}$ and matures in about
145 days. Its average grain yield is 23.0 quintals per acre. It is resistant to yellow and brown rusts and susceptible to loose smut.

\section{Design and layout}

The experiment will be laid out in a Randomized block design (RBD) with three replications. The experimental details and lay out plan are given below:

Crop : Wheat (Triticum aestivum L.).
Variety : PBW-550
Spacing $: 22.5 \mathrm{~cm} \times 10 \mathrm{~cm}$
Design : Randomized block design (RBD)
Replications $: 03$
Total treatments $: 09$
Gross plot $\quad: 2.5 \mathrm{~m} \times 1.5 \mathrm{~m}$
Irrigation channel : $0.5 \mathrm{~m}$

\section{Treatment details}

$\mathrm{T}_{1}-\mathrm{RDF}$

$\mathrm{T}_{2}$ - EC (1/4) basal + PM (3/4) basal

$\mathrm{T}_{3}$ - FYM (1/4) basal + VC (3/4) basal

$\mathrm{T}_{4}$ - FYM (1/4) basal + PM (3/4) basal

$\mathrm{T}_{5}-\mathrm{EC}(1 / 4)$ basal + VC (3/4) basal

$\mathrm{T}_{6}-\mathrm{FYM}(1 / 4)$ basal + PM (3/4) top dressing 30DAS

$\mathrm{T}_{7}-\mathrm{EC}(1 / 4)$ basal + VC (3/4) top dressing @ 30 DAS

$\mathrm{T}_{8}$ - EC (1/4) basal + PM (3/4) top dressing at 30DAS

$\mathrm{T}_{9}$ - Control

Note 1: All organics are made equivalent to recommended dose of nitrogen (RDN)

Note 2: FYM: Farm yard manure, VC: Vermicompost, PM: Poultry manure, EC: Enriched compost

Note 3: RDF (recommended dose of fertilizers 100:75:50 $\mathrm{kg} \mathrm{NPK} \mathrm{ha}^{-1}$ ) 


\section{Leaf area (LA) and leaf area index (LAI)}

Leaf area $\left(\mathrm{cm}^{2}\right)$ was computed with multiplied by length and then multiplied by correction factor 0.65n 30 DAS and 60 DAS and at harvest as given by Gomez (1976).

Leaf area index was worked out by dividing the leaf area per unit land area as given by (Sestak et al., 1971).

LAI $=\frac{\text { Leaf area per plant }\left(\mathrm{cm}^{2}\right.}{\text { Ground area per plant }\left(\mathrm{cm}^{2}\right)}$

\section{Number of tillers plant ${ }^{-1}$}

Number of tillers per metre row length from three places (marked with stick) from each plot will be counted at 60 DAS and at harvest.

\section{Results and Discussion}

The results of experiment conducted to study the effect of organic manures on growth, yield and grain quality of wheat (Triticum aestivum L.) during Rabi season 2018-2019 are presented in this paper.

\section{Leaf area $\left(\mathrm{cm}^{2}\right)$ and leaf area index}

Data pertaining to Leaf Area Index (LAI) at various stages as influenced by different treatments are presented in Table no.1 and depicted in Fig: 1

The leaf area and leaf area index significantly highest among the treatments at 30 and 60 DAS respectively in $\mathrm{T}_{8^{-}} \mathrm{EC}(1 / 4)$ basal + PM (3/4) top dressing @ 30 DAS (15.77, 24.12 and $1.670,2.637 \mathrm{~cm}^{2}$ respectively) recorded was on par with $\mathrm{T}_{6}$ - FYM (1/4) basal + PM (3/4) top dressing @ 30 DAS (15.63, 22.12 and 1.610, $2.473 \mathrm{~cm}^{2}$ respectively), $\mathrm{T}_{2}-\mathrm{EC}$ (1/4) basal + PM (3/4) basal (15.52, 22.60 and $1.583,2.343 \mathrm{~cm}^{2}$ respectively) the minimum plant height was recorded under $\mathrm{T}_{9}$ - Control $\left(12.96,17.25\right.$ and $\left.1.357,1.927 \mathrm{~cm}^{2}\right)$.

\section{Number effective tillers per plant}

Data pertaining to number of effective tillers per plant as influenced by different treatments are presented in Table no. 2 and depicted in Fig: 2

It is clearly noticed that $\mathrm{T}_{8^{-}} \mathrm{EC}(1 / 4)$ basal + PM (3/4) top dressing @ 30 DAS recorded the highest numbers of effective tillers at 60 DAS (116.00) and at harvest (126.66) which was one par with $\mathrm{T}_{6^{-}}$FYM (1/4) basal + PM (3/4) top dressing @ 30 DAS and $\mathrm{T}_{2}$ EC (1/4) basal + PM (3/4) basal at 60DAS (104.33 and 100.33 respectively) and at harvest (124 and 123.66 respectively). The lower number was recorded by $\mathrm{T}_{9}$ - Control at both stages (81.66 and 102.66).

Number of effective tillers per meter row length, leaf area and leaf area index at different growth stages as influenced by organic manures is given below.

The leaf area and leaf area index significantly highest among the treatments at 30,60, 70 DAS and at harvest, respectively in $\mathrm{T}_{8}-\mathrm{EC}$ (1/4) basal + PM (3/4) top dressing @ 30 DAS (15.77, 24.12, $1.67 \& 2.63 \mathrm{~cm}$ respectively) recorded was on par with $\mathrm{T}_{6^{-}}$ FYM (1/4) basal + PM (3/4) top dressing @ 30 DAS $(15.63,22.12,1.61 \& 2.47 \mathrm{~cm}$ respectively), $\mathrm{T}_{2}$ - EC (1/4) basal + PM (3/4) basal $(15.52, \quad 22.60, \quad 1.58 \quad \& \quad 2.34 \mathrm{~cm}$ respectively) the minimum was recorded under $\mathrm{T}_{9}$ - Control $(12.96,17.25,1.35 \& 1.92$ $\mathrm{cm})$. 
Table.1 Leaf area and Leaf area index (LAI) per meter row length at different Growth stages as influenced by organic manures

\begin{tabular}{|c|c|c|c|c|}
\hline \multirow[t]{2}{*}{ Treatments } & \multicolumn{2}{|c|}{ Leaf area } & \multicolumn{2}{|c|}{$\begin{array}{l}\text { Leaf area } \\
\text { Index }\end{array}$} \\
\hline & $\begin{array}{c}\text { 30 } \\
\text { DAS }\end{array}$ & $\begin{array}{c}\mathbf{6 0} \\
\text { DAS }\end{array}$ & $\begin{array}{c}30 \\
\text { DAS }\end{array}$ & $\begin{array}{c}60 \\
\text { DAS }\end{array}$ \\
\hline $\mathbf{T}_{1}-\mathbf{R D F}$ & 13.85 & 22.00 & 1.473 & 2.167 \\
\hline $\mathrm{T}_{2}-\mathrm{EC}(1 / 4)$ basal + PM (3/4) basal & 15.52 & 22.60 & 1.583 & 2.343 \\
\hline $\mathrm{T}_{3^{-}}$FYM (1/4) basal + VC (3/4) basal & 13.29 & 18.22 & 1.393 & 1.953 \\
\hline T$_{4}-$ FYM (1/4) basal + PM (3/4) basal & 13.67 & 20.08 & 1.467 & 2.047 \\
\hline $\mathrm{T}_{5}-\mathrm{EC}(1 / 4)$ basal + VC (3/4) basal & 13.46 & 18.26 & 1.413 & 1.987 \\
\hline T6- FYM (1/4) basal + PM (3/4)top dressing @ 30 DAS & 15.63 & 22.12 & 1.610 & 2.473 \\
\hline $\mathrm{T}_{7}$ - EC (1/4) basal + VC (3/4) top dressing @ $30 \mathrm{DAS}$ & 13.56 & 19.48 & 1.450 & 2.013 \\
\hline $\mathrm{T}_{8}$ - EC (1/4) basal + PM (3/4) top dressing @ 30 DAS & 15.77 & 24.12 & 1.670 & 2.637 \\
\hline$T_{9}-$ Control & 12.96 & 17.25 & 1.357 & 1.927 \\
\hline $\mathrm{CD}(\mathrm{p}=\mathbf{0 . 0 5})$ & 1.155 & 1.340 & 0.059 & 0.065 \\
\hline C.V. & 4.462 & 3.751 & 2.256 & 1.178 \\
\hline S.Em \pm & 0.382 & 0.443 & 0.019 & 0.022 \\
\hline
\end{tabular}

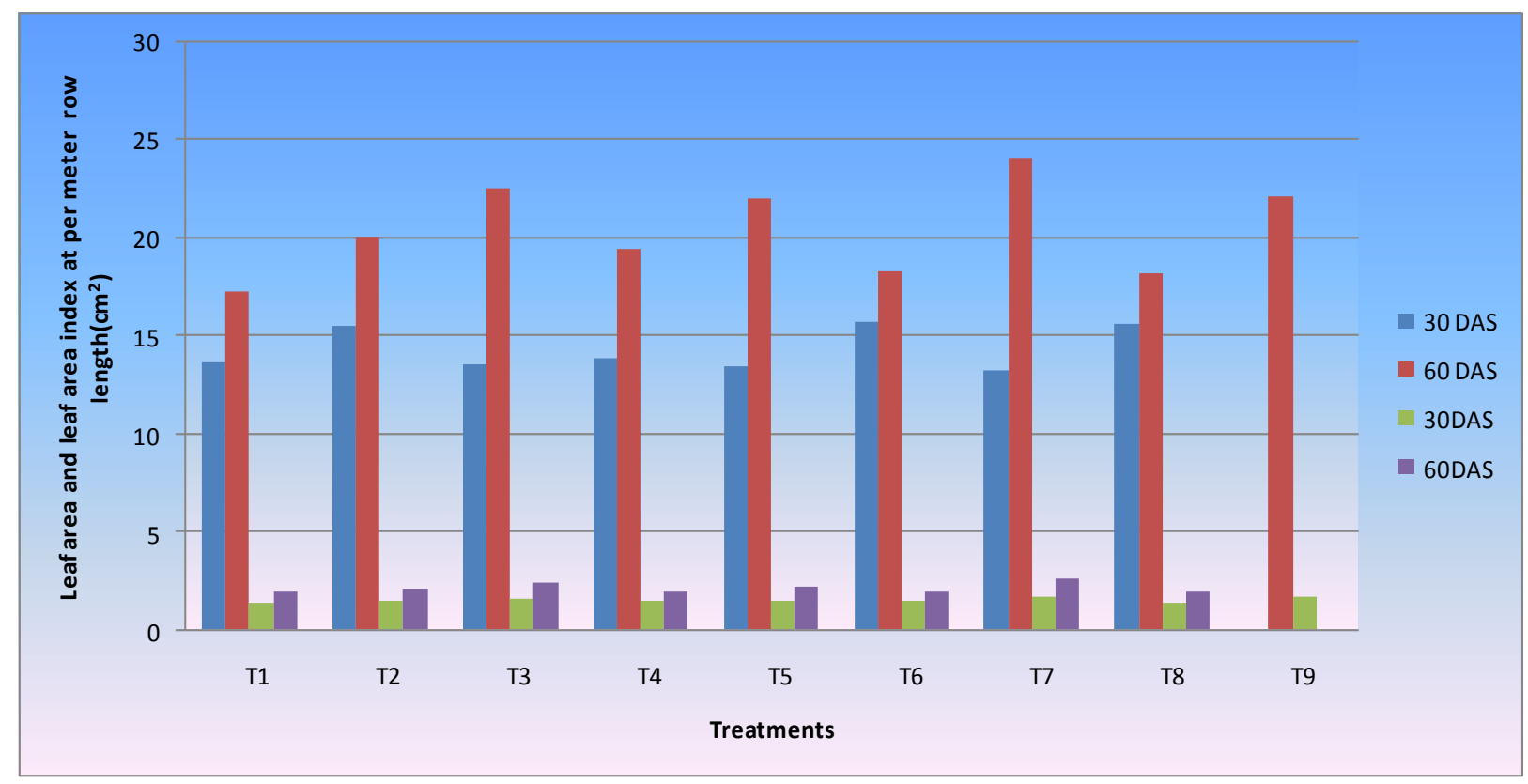

Fig.1 Leaf area and Leaf area index (LAI) per meter row length at different growth stages as influenced by organic manures 
Table.2 Number of effective tillers per meter row length at different growth stages as influenced by organic manures

\begin{tabular}{|c|c|c|}
\hline \multirow{2}{*}{ Treatments } & \multicolumn{2}{|c|}{ Number of effective tillers } \\
\hline & $\begin{array}{c}60 \\
\text { DAS }\end{array}$ & $\begin{array}{c}\text { At } \\
\text { Harvest }\end{array}$ \\
\hline $\mathbf{T}_{1-} \mathbf{R D F}$ & 93.66 & 118.33 \\
\hline $\mathrm{T}_{2-}$ EC (1/4) basal + PM (3/4) basal & 100.33 & 123.66 \\
\hline$T_{3}-$ FYM (1/4) basal + VC (3/4) basal & 85.33 & 104.00 \\
\hline$T_{4}-$ FYM (1/4) basal + PM (3/4) basal & 93.00 & 116.00 \\
\hline $\mathrm{T}_{5}-\mathrm{EC}(1 / 4) \mathrm{basal}+\mathrm{VC}(3 / 4)$ basal & 89.33 & 107.33 \\
\hline T6- FYM (1/4) basal + PM (3/4)top dressing @ 30 DAS & 104.33 & 124.00 \\
\hline $\mathrm{T}_{7}-\mathrm{EC}(1 / 4)$ basal + VC (3/4) top dressing @ 30 DAS & 90.00 & 113.00 \\
\hline$T_{8}-$ EC (1/4) basal + PM (3/4) top dressing @ 30 DAS & 116.00 & 126.66 \\
\hline $\mathbf{T}_{9}-$ Control & 81.66 & 102.66 \\
\hline $\mathrm{CD}(\mathrm{p}=0.05)$ & 3.701 & 3.205 \\
\hline C.V. & 2.235 & 1.595 \\
\hline S.Em \pm & 1.224 & 1.060 \\
\hline
\end{tabular}

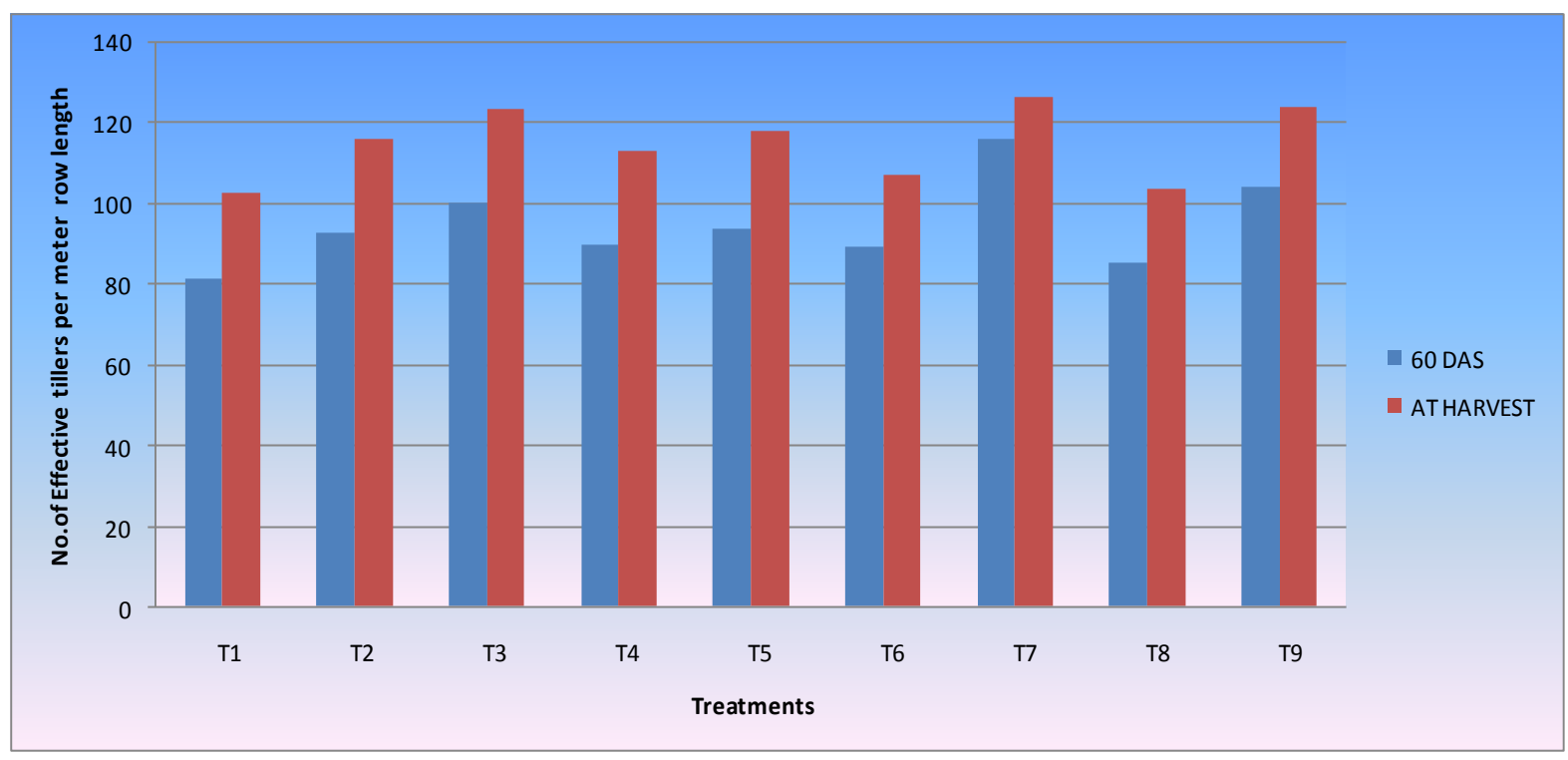

Fig.2 Number of effective tillers per meter row length at different growth stages as influenced by organic manures 
It is clearly noticed that maximum number of effective tillers per meter row length $\mathrm{T}_{8}-\mathrm{EC}$ (1/4) basal + PM (3/4) top dressing @ 30 DAS (116.00) and at harvest (126.66) which was on par with $\mathrm{T}_{6}-\mathrm{FYM}(1 / 4)$ basal + PM (3/4) top dressing @ 30 DAS and $\mathrm{T}_{2}$ - EC (1/4) basal + PM (3/4) basal at 60 DAS (104.33 and 100.33 respectively) and at harvest (124 and 123.66 respectively). The lower number was recorded by $\mathrm{T}_{9-}$ - Control at both stages as (81.66 and 102.66).

\section{References}

Arun Kumar, K., Karuna Sager, G., Chandrika, V and Reddy, P.M., (2009). Influence of integrated nitrogen management on yield, nitrogen uptake, soil fertility status and economics of baby corn. Indian Journal Agriculture Research 43(3): 227-229.

Gomez, K.A. and Gomez, A., (1976). Statistical procedures for Agricultural Research (2/E). John Willey and Sons, New York.

Sestak,Z., Castky, J and Jarris, P. G., (1971). Plant Analysis in Production Manual of Methods (Ed. Jonk, W.), N. V. N. V. Publications, The Hague, pp. 343-381.

Subbareddy, G., Maruthi, V and SreeRekha, M., (2008). Assessing the method of application of farmyard manure on dryland crops.Indian Journal of Agronomy, 49(2) : 104-107.

\section{How to cite this article:}

Siva Naga Lakshmi. Ch., Narendra Singh, Gajendra Singh, Ankush Singh and Pragya Rawat. 2020. Influence of Organic Manures on Number Effective Tillers Per Plant, Leaf Area (LA) and Leaf Area Index (LAI) in Wheat (Triticum Aestivum L.). Int.J.Curr.Microbiol.App.Sci. 9(03): 1382-1387. doi: https://doi.org/10.20546/ijcmas.2020.903.160 